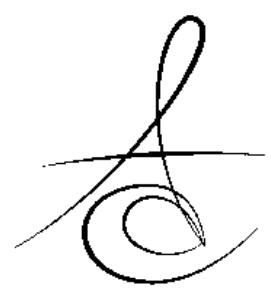

\section{EVAULATION OF EFFECTS OF DIFFERENT TOOTHBRUSH TYPES ON PERIODONTAL STATUS IN ORTHODONTIC PATIENTS}

\section{FARKLI DİŞ FIRÇASI TİPLERİNİN ORTODONTİ HASTALARINDA PERİODONTAL DURUMA ETKİLERİNİN KARŞILAŞTIRILMASI}

\author{
Doç. Dr. Süleyman Kutalmış BÜYÜK** \\ Uzm. Dr. Meltem ALTUN****
}

Makale Kodu/Article code: 4961

Makale Gönderilme tarihi; 04.04.2021

Kabul Tarihi: 14.07.2021

DOI : $10.17567 /$ ataunidfd. 977586
Mustafa Cihan Yavuz: ORCID ID: 0000-0002-2861-8828

Suleyman Kutalmış Büyük: ORCID ID: 0000-0002-7885-9582

Gökhan Türker: ORCID ID: 0000-0001-5295-2722

Meltem Altun: ORCID ID: 0000-0003-4262-747x

\title{
ABSTRACT
}

Aim: The aim of this study was to evaluate the plaque removal efficacy of soft bristles toothbrushes (SBTB) compared with medium bristles toothbrushes (MBTB) using clinical periodontal parameters in orthodontic patients with self-ligating brackets. Methods: A total of 32 orthodontic patients scheduled for fixed orthodontic treatment were selected for this prospective study. Patients were divided into randomly two groups brushing with tooth brusher type as follow SBTB and MBTB. The bonded bracket plaque index (PI), and pocket depth values (PDV) were evaluated 1 week after bracket placement (T1), 2 weeks after bracket placement (T2); and 3 weeks after bracket placement (T3). The Friedman and Mann Whitney $U$ tests were used to analyze the data based on the Bonferroni test.

Results: There was no statistically significant difference between the groups regarding PI and PDV values $(p>0.05)$. In the MBTB group, PDV values revealed statistically significant changes between T2 and T3 $(p<0.05)$. Moreover, pain scores showed no significant difference between the toothbrush groups $(p=0.540)$.

Conclusion: There were no differences in the periodontal parameters between the soft bristles toothbrushes and oft medium bristles toothbrushes in orthodontic patients with self-ligating brackets.

Key words: Self-ligating brackets, Oral hygiene, Periodontal status

öz

Amaç: Bu çalışmanın amacı yumuşak kıl formasyonuna sahip (SBTB) diş fırçası ile orta sertlikte kıl formasyonuna sahip (MBTB) diş fırçası tiplerinin kapaklı braketler ile tedavi edilen ortodonti hastalarında klinik periodontal parametreleri kaydedilerek plak kaldırma etkilerinin değerlendirilmesidir.

Gereç ve Yöntem: Bu prospektif çalışma için sabit ortodontik tedavi gören 32 ortodonti hastası seçilmiştir. Hastalar randomize olarak kullandıkları diş fırçası tipine göre SBTB ve MBTB olarak iki gruba ayrılmıştır. Plak indeksi (PI) ve sondalama cep derinliği (PPDV) braketler yerleştirildikten 1 hafta sonra (T1), 2 hafta sonra (T2) ve 3 hafta sonra (T3) olmak üzere değerlendirilmiştir. Friedman ve Mann Whitney $\mathrm{U}$ testleri ile Bonferroni düzeltmesi kullanılarak veriler analiz edilmiştir.

Bulgular: PI ve PPDV yönünden değerlendirildiğinde istatistiksel olarak anlamlı bir farklılık gözlenmemiştir (P> 0.05). MBTB grubunda, PDV değerleri T2 ve T3 tedavi zamanları arasında istatistiksel olarak anlamlı değişiklik göstermiştir $(P<0.05)$. Ayrıca, ağrı skorları gruplar arasında bir hafta sonunda anlamlı farklılık göstermemiştir $(P=0.540)$.

Sonuç: Yumuşak kıl formasyonuna sahip diş fırçası ile orta sertlikte kıl formasyonuna sahip diş fırçası tiplerinin kapaklı braket kullanılan ortodonti hastalarında periodontal parametreler açısından bir farklılığa sebep olmamıştır.

* Department of Periodontology, Faculty of Dentistry, Istanbul Medeniyet University, İstanbul.

${ }^{* *}$ Department of Orthodontics, Faculty of Dentistry, Ordu University, Ordu.

${ }^{* * *}$ Department of Orthodontics, Faculty of Dentistry, Mersin University, Mersin.

**** Private Practice, İstanbul, Turkey.

Kaynakça Bilgisi: Yavuz MC, Büyük SK, Türker G, Altun M. Farklı diş fırçası tiplerinin ortodonti hastalarında periodontal duruma etkilerinin karşılaştırıması. Atatürk Üniv Diş Hek Fak Derg 2021; 31: 433-8.

Citation Information: Yavuz MC, Buyuk SK, Turker G, Altun M. Evaulation of effects of different toothbrush types on periodontal status in orthodontic patients. J Dent Fac Atatürk Uni 2021; 31: 433-8.

\section{INTRODUCTION}

Fixed orthodontic treatment can cause worsening of oral hygiene because a fixed orthodontic appliance increases the number of retentive sites for plaque accumulation on the tooth surface, particularly between the gingival margin and bracket.1,2 Along with increasing retention areas, brushing becomes difficult. This difficulty in brushing facilitates an increased risk of demineralization, caries, and periodontal diseases at the fixed appliance sites. ${ }^{3}$ 
After the application of fixed orthodontic appliances, an increase in pocket probe depth and bleeding on probing occurs. ${ }^{4}$ Tooth brushing efficacy can be clinically evaluated by gingival index, bleeding index, and plaque index. ${ }^{5}$ Chang et al. ${ }^{6}$ reported that there is a statistically significant increase in $\mathrm{pH}$, plaque index scores, and the levels of Streptococcus mutans and lactobacilli after 3 months of active orthodontic treatment.

Good oral hygiene is characterized by good periodontal and dental health during orthodontic treatment. ${ }^{7}$ If acceptable oral hygiene cannot be achieved, orthodontic treatment becomes complicated and develops side effects. ${ }^{8}$ Dental plaque causes most periodontal diseases and dental caries. Therefore, plaque control, including correct tooth brushing, must be provided to prevent periodontal problems during orthodontic treatment. ${ }^{9}$

There are many types of toothbrushes based on the size, length, hardness, and arrangement of bristles. There is a lack of evidence in the literature as to which toothbrush design is superior in terms of its efficacy in plaque removal. ${ }^{10}$ Actually, toothbrushes with soft bristles are appropriate for removing plaque efficiently. ${ }^{11}$

Toothbrush manufacturers aim to develop design features for better removal efficacy. There are different opinions in the literature concerning the effectiveness of manual and electric toothbrushes in terms of removing plaque. ${ }^{12,13}$ In a systematic review, Robinson et al. ${ }^{12}$ discovered that an electric toothbrush with a rotation-oscillation action reduced plaque more than a manual tooth brush. On the other hand, Vibhute et al. reported no differences between electric and manual toothbrushes. ${ }^{13}$

To overcome the side effects of conventional brackets, self-ligating brackets (SLBs) were manufactured and gained popularity in recent years. SLBs are less complex than conventional brackets, reduce chair time, and have biomechanical advantages. ${ }^{14,15}$ SLBs have fewer retentive sites for plaque accumulation and do not require wire and elastomeric ligatures. ${ }^{15}$ Pellegrini et al. ${ }^{16}$ showed that SLBs are less likely to accumulate dental plaque compared with conventional brackets.

The aim of this study was to evaluate the plaque removal efficacy of soft-bristle toothbrushes (SBTB) compared with medium-bristle toothbrushes (MBTB) using clinical periodontal parameters in orthodontic patients with self-ligating brackets.

\section{MATERIALS AND METHODS}

The sample size for the study was calculated using G*Power program. Power analysis presented that for a power of $0.90,16$ patients would be required for each group for plaque index (PI). The present study involved 32 patients aged between 13 and 18 years who were patients of the Department of Orthodontics, Faculty of Dentistry, Ordu University, Turkey for fixed orthodontic treatment. Ethical approval was obtained from the regional ethical committee of the Ordu University. Informed consent was obtained from all patients. All patients had permanent dentition, were free of dental plaque, had mild to moderate crowding of maxillary and mandibular dental arches, and were motivated for good oral hygiene. Fixed ort- hodontic treatment was performed with SLBs (Empo- wer bracket, American Orthodontist, USA). SLBs were ligated with 0.012-inch nickel-titanium wire. Patients were divided randomly into two groups, brushing with toothbrush types as follows: group 1: soft-bristle toothbrushes (Tepe Munhygienprodukter $A B$, Sweden) and group 2: medium-bristle toothbrushhes (Tepe Munhygienprodukter $A B$, Sweden). The distribution of the average age and gender of the groups is summarized in Table 1. An experienced dentist (M.A.) gave formal oral hygiene instructions to each patient for the allocated brush, first demonstra- ting on a set of plastic models of the dental arches fitted with upper and lower fixed appliances. Each patient was issued a fluoride-containing toothpaste (Colgate Great Regular Flavor, Colgate-Palmolive Ltd, Guildford, UK). All patients were told to brush their teeth after each meal with the 'Modified Bass method'. For both groups, the following clinical periodontal variables were evaluated 1 week after bracket placement (T1), 2 weeks after bracket placement (T2), and 3 weeks after bracket placement (T3). All clinical periodontal measurements were performed by the same investigator at each control appointment (M.A.). The same investigator evaluated the periodontal status with a Williams periodontal probe. The bonded bracket PI, ${ }^{17}$ and pocket depth values (PDV) were performed for maxillary anterior teeth periodontal status evaluation.

Following the first archwire insertion (0.012 Ni$\mathrm{Ti}$ in the treatment groups), the patients were given a discomfort diary to complete over the first week. The diary recorded discomfort by means of a $100-\mathrm{mm}$ visual analog scale (VAS) at 1 week. The patients completed the VAS diary for the maxillary arch. 


\section{Statistical analysis}

The data were evaluated with SPSS version 15.0 software for Windows (SPSS Inc, Chicago, IL, USA). The Shapiro-Wilk test was performed to test for normal distribution. The Friedman and Mann-Whitney $U$ tests were used for the comparison of parameters between times and groups. The age distribution in each group was compared using the independentsample $t$-test. The gender distribution in each group was evaluated by means of a Pearson chi-square test. The significance level was set at $a=0.05$ for all statistical analyses.

\section{RESULTS}

There was no significant age difference between groups (Table 1). The mean values of VAS, PI, and PVD scores are given in Tables 2-4.

For PI and PDV scores, neither group displayed a significant difference with time. While mean plaque index scores in the SBTB group decreased consistently ( $P=0.867)$, in the MBTB group, this value decreased between T1 and T2 and increased between T2 and T3 $(P=0.327)$. The intergroup comparison of $\mathrm{PI}$ measurements showed no significant difference at all time intervals, while the PDV scores comparison in the T2-T3 time interval of the MBTB group showed a significant difference $(P<0.05$; Tables 3 and 4). However, the PDV scores of the MBTB group were lower. Moreover, the VAS scores showed no significant difference between the toothbrush groups $(P=0.540$; Table 2).

Table 1. The distribution of the average age (years) and gender of the different toothbrush types groups

\begin{tabular}{lcccccc}
\hline & $\mathrm{n}$ & Male & Female & $P^{*}$ & Mean $\pm \mathrm{SD}$ & $P^{* *}$ \\
\hline SBTB & 16 & 9 & 7 & 0.066 & $15.15 \pm 1.76$ & 0.962 \\
MBTB & 16 & 3 & 13 & & $15.32 \pm 2.51$ & \\
\hline
\end{tabular}

SD indicates standart deviation; SBTB indicates Soft Bristles Tooth Brush, MBTB indicates Medium Bristles Tooth Brush.

$* X^{2}$ significance level.

$* *$ t- test significance level

Table 2. Comparison of VAS score changes of the groups at the one week later.

\begin{tabular}{cccccc}
\hline \multicolumn{7}{c}{ Percentiles } & & \\
\hline & $\mathrm{n}$ & 25 th & 50th (Median) & 75th & $P^{*}$ \\
\hline SBTB & 16 & 0.00 & 2.50 & 4.75 & \\
& & & 2.50 & 4.50 & 0.540 \\
MBTB & 16 & 1.00 & &
\end{tabular}

SD indicates standart deviation; SBTB indicates Soft Bristles Tooth Brush, MBTB indicates Medium Bristles Tooth Brush.

* Mann-Whitney U significance level.
Table 3. Comparison of mean plaque index scores between and within the different toothbrush groups at three evaluation times (T1, T2 and T3) and changes between times.

\begin{tabular}{lccccccc}
\hline & $\mathrm{T} 1$ & $\mathrm{~T} 2$ & $\mathrm{~T} 3$ & \multicolumn{3}{c}{ Significance Between Times } \\
\hline & Mean \pm SD & Mean \pm SD & Mean \pm SD & $p^{*}$ & T1-T2 & T1-T3 & T2-T3 \\
\hline SBTB & $0.73 \pm 0.50$ & $0.65 \pm 0.43$ & $0.62 \pm 0.51$ & 0.867 & 0.979 & 0.589 & 0.918 \\
MBTB & $0.67 \pm 0.50$ & $0.58 \pm 0.56$ & $0.88 \pm 0.63$ & 0.327 & 0.650 & 0.173 & 0.177
\end{tabular}

$\begin{array}{llll}P * * & 0.637 & 0.406 & 0.287\end{array}$

T1 indicates 1 week after bonding; T2, 2 weeks after bonding; T3, 3 weeks after bonding; SD indicates standard deviation; SBTB indicates Soft Bristles Tooth Brush; MBTB, Medium Bristles Tooth Brush.

* Friedman test significance level within the brush groups.

** Mann-Whitney U significance level between the brush groups.

Table 4. Comparison of mean probing pocket depth value scores between and within the brush groups at three evaluation times ( $t 1, t 2$ and $t 3)$ and changes between times.

\begin{tabular}{lccccccc}
\hline & T1 & T2 & T3 & \multicolumn{3}{c}{ Significance Between Times } \\
\hline & Mean \pm SD & Mean \pm SD & Mean \pm SD & $p^{*}$ & T1-T2 & T1-T3 & T2-T3 \\
\hline SBTB & $2.20 \pm 0.46$ & $2.03 \pm 0.60$ & $2.11 \pm 0.41$ & 0.808 & 0.363 & 0.244 & 0.925 \\
MBTB & $2.34 \pm 0.44$ & $2.40 \pm 0.42$ & $2.23 \pm 0.34$ & 0.087 & 0.426 & 0.093 & 0.038 \\
$p^{* *}$ & 0.381 & 0.110 & 0.323 & & & & \\
\hline
\end{tabular}

T1 indicates 1 week after bonding; T2, 2 weeks after bonding; T3, 3 weeks after bonding; SD indicates standard deviation; SBTB indicates Soft Bristles Tooth Brush; MBTB, Medium Bristles Tooth Brush.

* Friedman test significance level within the brush groups. The significance level was $\mathrm{P}<0.017$ based on the Bonferroni test.

** Mann-Whitney $U$ significance level between the brush groups.

\section{DISCUSSION}

The presence of a fixed orthodontic appliance results in plaque accumulation between the bracket and gingival margin because of the difficulty it imposes on tooth brushing. ${ }^{1}$ Therefore, orthodontic brackets may contribute to the development of an inflammatory process. ${ }^{18}$ After the application of fixed orthodontic appliances, the microbiological environment of the oral cavity changes, and periodontal pocket depth and bleeding on probing may increase as a result of this application. ${ }^{19,20}$ The aim of our study was to compare the effect of SBTB and MBTB on the PI, PDV, and VAS scores and to the best of our knowledge, this is the first study that clinically shows the influences of the use of toothbrush bristles of different stiffnesses in orthodontic patients.

With conventional brackets, steel or elastomeric ligatures are needed to fix archwire in bracket slots. Thus, the use of these brackets, particularly with elastomeric ligatures, is associated with increased bacterial colonization in the form of plaque and the values of the periodontal parameters during treatment may be increased due to the plaque-retentive effect of conventional brackets. ${ }^{14,16}$ The use of SLBs eliminates this side effect of conventional brackets ligatures and

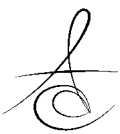


promotes oral hygiene due to their concise configuration design without the ligature of SLBs. ${ }^{21}$ In this study, SLBs were preferred because they were shown to have fewer retentive sites and because they could be standardize.

The oral hygiene program in our study was standardized by motivation of all patients to brush and by giving all subjects the same toothpaste. In addition, all patients who were included in the study were at the same stage of orthodontic treatment.

Optimal oral hygiene requires professional instructions, adequate tools, and patient motivation. ${ }^{22}$ However, there is no consensus in the literature as to the most effective toothbrush type for removing plaque. Heasman et al. ${ }^{18}$ found that there were no differences with respect to the effectiveness of reducing plaque and reducing gingival bleeding between electric toothbrushes and manual toothbrushes in 60 orthodontic patients. On the other hand, Robinson et al. ${ }^{12}$ showed that an electric toothbrush with a rotation-oscillation action reduced plaque more than a manual tooth brush in their systematic review. Recently, Erbe et al. ${ }^{23}$ evaluated the efficacy of a rotation-oscillation electric toothbrush with an orthodontic brush head, the same toothbrush with a regular brush head, and regular manual toothbrush treatments in plaque removal in orthodontic patients, and reported that the electric toothbrush with both brush heads was more effective than the manual brush in plaque removal and the orthodontic brush head was superior to the regular head. In our study, the plaque removal efficacies of the SBTB and MBTB were evaluated using clinical periodontal parameters in orthodontic patients.

Our study investigated the effectiveness of manual toothbrushes of the same type with different bristle stiffness. In another study ${ }^{24}, 20$ soft toothbrushes were compared with the ADA standard toothbrush in non-orthodontic patients, comparing different bristle stiffness and toothbrush design. Zimmer et al. ${ }^{25}$ reported that a toothbrush with hard bristles may better remove plaque, but may also abrade the gingival epithelium and cause more bleeding compared with toothbrushes with softer bristles. Therefore, a toothbrush with hard bristles was not included in our study because bleeding indexes could be affected by this types of bristles.

Many studies ${ }^{1-2-26}$ reported that orthodontic appliances increased the accumulation of dental plaque on the tooth surface, particularly between the gingival margin and bracket. Plaque index describes the severity and location of the soft debris aggregates on the tooth. ${ }^{17}$ The results of our study show that there was no significant difference in PI scores during the study in two groups and that PDV scores did not show any significant difference between groups. The intergroup comparison of PDV scores in the T2-T3 time interval in the MBTB group showed a significant decrease. Because we performed this study in a limited time period of 3 weeks, long-term studies may be needed for the evaluation of PDV scores in orthodontic patients. These results show that both SBTB and MBTB are equally effective in the preservation of oral hygiene.

Several studies 27,29 showed that patients with fixed orthodontic appliances reported pain from their appliances and pain peaked $24 \mathrm{~h}$ after the start of the treatment. Pain started to decrease on the second day and reached a minimum at the seventh day after archwire placement. ${ }^{30}$ However, an important parameter in the use of any type of toothbrush is discomfort or pain for patients. ${ }^{31}$ In our study, it was difficult to identify pain etiology. Pain may be caused by the beginning of the orthodontic treatment or toothbrush stiffness, therefore our study was started 1 week after archwire placement. In the present study, the VAS scores showed no significant difference between the toothbrush groups.

The present study shows that there is no difference in effectiveness between soft toothbrushes and toothbrushes of medium stiffness for orthodontic patients. Future studies can focus on finding the optimal bristle stiffness in relation to maximum efficacy to provide oral hygiene during active orthodontic treatment.

\section{Authors' contributions}

MCY, SKB and GT conceived this clinical research, and wrote the manuscript. SKB and MA helped collecting the data. SKB, performed the statistical analysis. MCY revised the manuscript and supervised the study.

Ethics

This study was approved by the local ethics committee Ordu, Turkey. Participation was voluntary, and privacy and confidentiality of all study information was maintained. Written informed consent was obtained from all patients and parents.

Acknowledgements

Not applicable.

Competing interests

The authors declare that they have no competing interests. 


\section{REFERENCES}

1. Ciancio D, Cunat J, Mather M, Harvey D. A comparison of plaque accumulation in bonded versus banded teeth. J Dent Res 1985;64:325.

2. Türkkahraman $H$, Sayin $M$, Bozkurt FY, Yetkin $Z$, Kaya S, Önal S. Archwire ligation techniques, microbial colonization, and periodontal status in orthodontically treated patients. Angle Orthod 2005;75: 231-6.

3. Feil PH, Grauer JS, Gadbury-Amyot CC, Kula K, McCunniff MD. Intentional use of the Hawthorne effect to improve oral hygiene compliance in orthodontic patients. J Dent Educ 2002;66: 112935.

4. Ristic M, Svabic MV, Sasic M, Zelic O. Clinical and microbiological effects of fixed orthodontic appliances on periodontal tissues in adolescents. Orthod Craniofac Res 2007;10: 187-95.

5. Bardal PAP, Olympio KPK, Bastos JRDM, Henriques JFC, Buzalaf MAR. Education and motivation in oral health: preventing disease and promoting health in patients undergoing orthodontic treatment. Dent Press J Orthod 2011; 16: 95-102.

6. Chang HS, Walsh $\sqcup$, Freer TJ. The effect of orthodontic treatment on salivary flow, $\mathrm{pH}$, buffer capacity, and levels of mutans streptococci and lactobacilli. Aust Orthod J 1999;15: 229-34.

7. Zachrisson BU. Cause and prevention of injuries to teeth and supporting structures during orthodontic treatment. Am J Orthod 1976;69: 285-300.

8. Machen DE. Legal aspects of orthodontic practice: risk management concepts. Periodontal evaluation and updates: don't abdicate your duty to diagnose and supervise. Am J I Orthod Dentofac Orthop 1990;98: 84-5.

9. Kloehn JS, Pfeifer JS. The effect of orthodontic treatment on the periodontium. Angle Orthod 1974;44: 127-34.

10. Slot DE, Wiggelinkhuizen $L$, Rosema NAM, Van der Weijden GA. The efficacy of manual toothbrushes following a brushing exercise: a systematic review. Int J Dent Hygi 2012;10: 187-97.

11. Schmickler J, Wurbs S, Wurbs S, Lange K, Rinke S, Hornecker E, Mausberg RF, Ziebolz D. Influence of the utilization time of different manual toothbrushes on oral hygiene assessed during a 6month observation period: A randomized clinical trial. J Periodontol 2014;85: 1050-8.
12. Robinson PG, Deacon SA, Deery $C$, Heanue $M$, Walmsley AD, Worthington HV, Shaw WC. Manual versus powered toothbrushing for oral health. Cochrane Database System Review 2005;18: CD002281.

13. Vibhute A, Vandana KL. The effectiveness of manual versus powered toothbrushes for plaque removal and gingival health: a meta-analysis. J Ind Soc Periodontol 2012;16: 156-60.

14. Nalçaci R, Özat $Y$, Çokakoglu S, Türkkahraman $H$, Önal S, Kaya S. Effect of bracket type on halitosis, periodontal status, and microbial colonization. Angle Orthod 2013;84: 479-85.

15. Pandis N, Papaioannou W, Kontou E, Nakou M, Makou M, Eliades T. Salivary Streptococcus mutans levels in patients with conventional and selfligating brackets. Eur J Orthod 2010; 32: 94-9.

16. Pellegrini $P$, Sauerwein R, Finlayson T, McLeod J, Covell DA, Maier T, Machida CA. Plaque retention by self-ligating vs elastomeric orthodontic brackets: quantitative comparison of oral bacteria and detection with adenosine triphosphate-driven bioluminescence. Am J Orthod Dentofac Orthop 2009;135: 426-e1-e9..

17. Löe $H$. The gingival index, the plaque index and the retention index systems. J Periodontol 1967; 38: $610-16$.

18. Heasman P, Wilson Z, Macgregor I, Kelly P. Comparative study of electric and manual toothbrushes in patients with fixed orthodontic appliances. Am J Orthod Dentofacial Orthop 1998;114: 45-9.

19. Da'ameh MDA, Al-Shorman I, Al-Shdeifat N, Fnaish MM. Oral hygiene measures in orthodontic treatment in Northern Jordan. Pakistan Oral Dent J 2011;31: 336-9.

20. Davis SM, Plonka AB, Fulks BA, Taylor KA, Bashutski J. Consequences of orthodontic treatment on periodontal health: clinical and microbiological effects. Semin Orthod s 2014;20: 139-49.

21. Yang X, Su N, Shi Z, Xiang Z, He Y, Han X, Bai D. Effects of self-ligating brackets on oral hygiene and discomfort: a systematic review and meta-analysis of randomized controlled clinical trials. Int J Dental Hygiene 2017;15:16-22.

22. Van Der Weijden F, Slot DE. Oral hygiene in the prevention of periodontal diseases: the evidence. Periodontology 2000 2011; 55: 104-23. 
23. Erbe C, Klukowska M, Tsaknaki I, Timm H, Grender J, Wehrbein H. Efficacy of 3 toothbrush treatments on plaque removal in orthodontic patients assessed with digital plaque imaging: a randomized controlled trial. Am J Orthod Dentofac Orthop 2013;143: 760-6.

24. Versteeg PA, Piscaer M, Rosema NAM, Timmerman MF, Van der Velden $U$, Van der Weijden GA. Tapered toothbrush filaments in relation to gingival abrasion, removal of plaque and treatment of gingivitis. Int J Dental Hygiene 2008;6: 174-82.

25. Zimmer $S$, Öztürk $M$, Barthel $C R$, Bizhang $M$, Jordan RA. Cleaning efficacy and soft tissue trauma after use of manual toothbrushes with different bristle stiffness. J Periodontol 2011;82: 267-71.

26. Sallum EJ, Nouer DF, Klein MI, Gonçalves RB, Machion L, Sallum AW, Sallum, EA. Clinical and microbiologic changes after removal of orthodontic appliances. Am J f Orthod Dentofac Orthop 2004;126: 363-6.

27. Kvam E, Bondevik O, Gjerdet NR. Traumatic ulcers and pain in adults during orthodontic treatment. Comm Dent Oral Epidemiol 1989;17: 154-7.

28. Bergius M, Kiliaridis $S$, Berggren $U$ Pain in orthodontics. A review and discussion of the literature. J Orofac Orthop 2000;61: 125-37.

29. Ngan P, Kess B, Wilson S. Perception of discomfort by patients undergoing orthodontic treatment. Am J Orthod Dentofac Orthop 1989; 96: 47-53.

30. Polat O, Karaman AI. Pain control during fixed orthodontic appliance therapy. Angle Orthod 2005 ; 75: 214-9.

31. Bock NC, von Bremen J, Kraft M, Ruf S. Plaque control effectiveness and handling of interdental brushes during multibracket treatment: a randomized clinical trial. Eur J Orthod 2010;32: 408-13.

\section{Sorumlu Yazarın Yazışma Adresi}

Mustafa Cihan YAVUZ

Department of Periodontology,

Faculty of Dentistry,

Medeniyet University,

İstanbul, 34100 TURKEY

Tel: +905056426856

E-mail address: muscyz111@gmail.com 